\title{
Distillery Anaerobic Digestion Residues as Fertilizers for Field Vegetable Crops: Performance and Efficiency in Mid-term Successions
}

\author{
Carlo Nicoletto $^{1, *(\mathbb{C} \text {, Luisa Dalla Costa }}{ }^{2}$, Paolo Sambo ${ }^{1}$ (1) and Giampaolo Zanin ${ }^{1}$ (I) \\ 1 Department of Agronomy, Food, Natural Resources, Animals and Environment (DAFNAE), \\ University of Padova, Viale dell'Università 16, 35020 Legnaro, Italy \\ 2 Department of Agricultural, Food, Environmental and Animal Science (Di4A), University of Udine, \\ Via delle Scienze 206, 33100 Udine, Italy \\ * Correspondence: carlo.nicoletto@unipd.it; Tel.: +39-049-827-2826
}

Received: 25 June 2019; Accepted: 15 August 2019; Published: 17 August 2019

\begin{abstract}
Understanding nitrogen use efficiency (NUE) of crops plays an important role in achieving sustainable production. Intensive agriculture has adversely affected social and environmental issues worldwide over the past few decades. Anaerobic digested residues from the distillery industry (DADRs) can be used in agriculture, thereby recycling valuable organic materials that can supply organic N. An experiment using DADRs in horticulture was conducted to evaluate the performance of different treatments on yield and NUE. The experiment was conducted for five years, growing lettuce, cauliflower, chicory, potato, Swiss chard, catalogna chicory, tomato, pepper, and melon in two different succession schemes. Five fertilization treatments were designed, including a mineral fertilization control, in which nitrogen $(\mathrm{N})$ was supplied according to standard recommendations in the area. The other treatments were an unfertilized control and three treatments in which $50 \%, 75 \%$, and $100 \%$ of the $\mathrm{N}$ were supplied by DADRs and the remaining with common chemical fertilizer. Major findings were: (1) Spring-summer crops showed the lowest N-uptake and N recovery, during this period high chemical fertilization can cause environmental problems such as $\mathrm{N}$ leaching, and fertilization with $100 \%$ DADRs is a viable alternative; (2) fall-winter crops can be fertilized by combining $50 \%$ mineral $\mathrm{N}$ and $50 \%$ organic $\mathrm{N}$, supplying the nutrients required by the crops during the growing cycle.
\end{abstract}

Keywords: organic fertilizer; nitrogen use efficiency; sustainable horticulture; agronomic efficiency; physiological efficiency; apparent recovery efficiency

\section{Introduction}

Soil fertility management is a crucial practice for vegetable growers facing the reduction of soil organic matter (SOM) as an obvious consequence of intensive horticultural cropping systems [1,2] and the abundant use of mineral fertilizers. To counteract the progressive loss of SOM, a regular incorporation of crop residues and/or organic fertilizers from animal farming such as farm manures and slurries (cattle and pig) can be adopted, which are also effective in improving soil nutritional status [3]. Another possible practice includes the integration of composts from urban food residues, from agro-industry, or from food processing by-products [4]. These actions and strategies are focused on making the agricultural system sustainable, that is "capable of being maintained at a steady level without exhausting natural resources or causing severe ecological damage" [5]. The incorporation of different organic residues can improve the nitrogen $(\mathrm{N})$ availability in the soil, which is linked to the organic material characteristics [3]. Possible amendments usable as potential soil fertilizers are the 
anaerobic digestion residues, which are gaining relevance in Northern Europe and Italy, especially with the increasing presence of digesters for biogas production [6].

Little attention has been paid to digestate effectiveness as organic amendments and/or organic fertilizers [7] and their agricultural functions [8]. A recent literature review underlines the tendency of the studies on digestate to focus on products of mainly animal derivation [9], and concentrate on technical aspects of their production $[10,11]$ such as pathogenicity, putrescibility, and foul odors [7]. Moreover, the organic fertilizers incorporated in the soil are often studied in confined laboratory tests $[12,13]$. Digestates from crop sources and food industry wastes are characterized by a more stable composition from a chemical point of view, as their nutrients concentration tends to fluctuate less [14]. A study on digestate use as fertilizer for vegetable crops indicates their high suitability for vegetable crop growth, even at low soil temperatures, often occurring with early sowings and cultivations [15]. In particular, digestates from crop residues and wastes of the food industry, such as vinasses, molasses, rapeseed meal, and municipal waste can be of great interest due to their quick $\mathrm{N}$-release. This feature is comparable to, or even higher than, the N-release of many commercial organic fertilizers often used for vegetable crops [7]. The use of digestates as soil amendments/fertilizer has given variable results in field crops, particularly on yield, depending on amendment origin and digestion process. Some authors address the use of digestates as fertilizer for vegetables showing that digestates are an effective nutrient source $[7,15,16]$. However, much of the information available in the literature refers to the use of animal origin digestates that have very variable nutrient concentrations according to the animal's diet [15]. Considering the main macronutrients, Möller and Müller [12] highlighted that the concentration of $\mathrm{N}$ can vary from $3.1 \%$ to $14 \%$, P from $0.6 \%$ to $1.7 \%$, and $\mathrm{K}$ from $1.9 \%$ to $4.3 \%$. Experimental trials linked to the use of digestates derived from plant materials are very scarce [17-20]. Many of them refer to arable-industrial crops [21] and microalgae [22]. Even less abundant are digestate studies on vegetable crops rotation, especially of mid-term period. Literature does not report extended results about distillery anaerobic digested residues (DADRs) [23]. This category of digestates represents an interesting opportunity for the Italian context, characterized by high wine production and, consequently, distinguished by considerable production of waste related to the transformation of grapes. In fact, recent estimates indicate that the quantity of exhausted grape pomace and dregs that could potentially be used for anaerobic digestion exceeds 800,000 tons [24] and could represent a disposal problem after digestion.

Vegetable crop successions tend to be quite rapid in specialized horticultural farms, and the ability of crops to intercept the nutritional compounds released by the mineralization depends on several characteristics: Rooting system architecture, crop growing season, and ability to withstand temporary water shortage [2]. Differences in nitrogen use efficiency (NUE) are well known at crop level and also at cultivar level [25]. Thus, the crop succession planned for the farm can drive the soil nutritional status towards accumulation or depletion of $\mathrm{N}$ and SOM [26]. Currently, the overall purpose for some authors is to study the genetics of NUE [27], find methods to increase N use efficiency (NUE), and reduce nutrient losses and $\mathrm{N}$ leaching $[28,29]$.

The experiment described here aimed to evaluate the application of DADRs in mid-term vegetable crop successions as a partial or complete substitution of mineral nitrogen sources in crop fertilization. NUE was measured as a tool to evaluate the environmental outcome of this practice and its sustainability.

\section{Materials and Methods}

\subsection{Experimental Structure}

The experiment was conducted for five years at the experimental farm "Lucio Toniolo", University of Padova, Northeastern Italy $\left(45^{\circ} 21^{\prime} \mathrm{N}\right.$ latitude; $11^{\circ} 58^{\prime} \mathrm{E}$ longitude; $6 \mathrm{~m}$ a.s.l.); meteorological data recorded during the trial period are reported in Figure 1. The chemical composition of the silty-loam soil (FAO) where the trial was performed is reported in Table 1. DADRs, a by-product from the 
distillery Mazzari s.p.a. (Ravenna, Italy) derived from fruit and dregs, were used as fertilizer in open field horticulture.
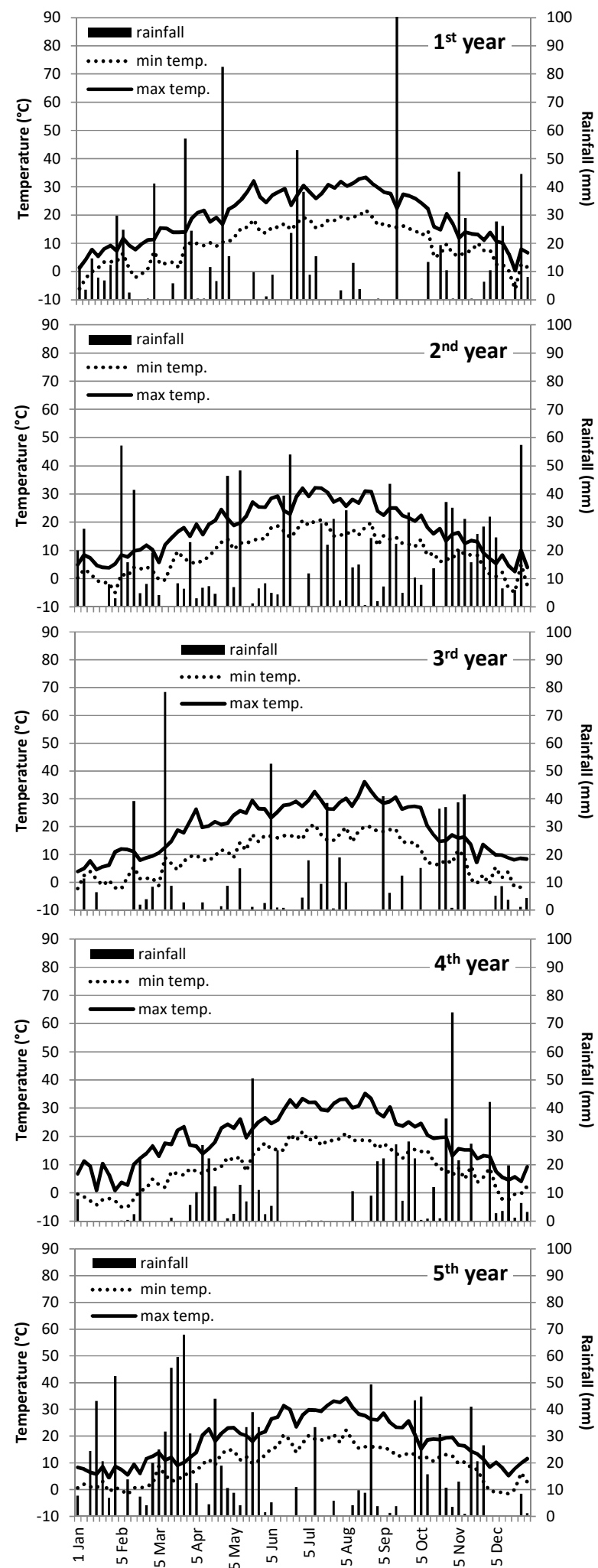

Figure 1. Meteorological data recorded during the five-year experiment. 
Table 1. Chemical properties of soil used for the experiment at different depths on a dry matter basis.

\begin{tabular}{cccc}
\hline \multirow{2}{*}{ Parameters } & \multicolumn{2}{c}{ Soil Depth } \\
\cline { 3 - 4 } & & $\mathbf{0 - 0 . 2 0 ~} \mathbf{~ m}$ & $\mathbf{0 . 2 0 - 0 . 4 0 ~} \mathbf{~ m}$ \\
\hline $\mathrm{pH}$ & & 7.35 & 7.30 \\
$\mathrm{EC}$ & $\mu \mathrm{S} \mathrm{cm}^{-1}$ & 250 & 250 \\
$\mathrm{NO}_{3}{ }^{-}$ & $\mathrm{mg} \mathrm{kg}^{-1}$ & 101 & 87 \\
$\mathrm{~K}^{+}$ & $\mathrm{mg} \mathrm{kg}^{-1}$ & 94 & 61 \\
$\mathrm{PO}_{4}{ }^{3-}$ & $\mathrm{mg} \mathrm{kg}^{-1}$ & 100 & 213 \\
$\mathrm{Na}^{+}$ & $\mathrm{mg} \mathrm{kg}^{-1}$ & 2921 & 2283 \\
$\mathrm{NH}_{4}^{+}$ & $\mathrm{mg} \mathrm{kg}^{-1}$ & 49 & 24 \\
$\mathrm{Cl}^{-}$ & $\mathrm{mg} \mathrm{kg}^{-1}$ & 187 & 228 \\
\hline \multicolumn{3}{c}{ EC: Electrical conductivity (EN13038). }
\end{tabular}

Three fertilization treatments were tested using DADRs to partially or completely replace mineral $\mathrm{N}$ crop requirement: $50 \% \mathrm{~N}$ through DADRs and 50\% $\mathrm{N}$ through mineral fertilizer (T50), $75 \% \mathrm{~N}$ through DADRs and 25\% $\mathrm{N}$ through mineral fertilizer (T75), and 100\% $\mathrm{N}$ through DADRs (T100). Two control treatments were included, one unfertilized (T0), and one with only mineral fertilization (TMIN). The P and K contents in the DADRs were taken into consideration to calculate the additional amount of $\mathrm{P}$ and $\mathrm{K}$ minerals to supply in the different treatments to provide the same quantity of these macronutrients. N, P, and K rates from mineral fertilizers were supplied, for the listed crops, according to standard recommendations in the area [30].

DADRs were analyzed (three replicates) and results are reported in Table 2, along with the used methodologies. Treatments were applied to different crops in two crop successions of five years. Species and varieties adopted in the different years, and their fertilization requirements, are reported in Table 3.

\subsection{Experimental Design}

The experiment was a strip plot design with three replicates; the main plot factor was the crop succession and the fertilization treatment was applied in strips randomly within replicates. The experimental unit area was $30 \mathrm{~m}^{2}$ wide $(7.5 \mathrm{~m} \times 4.0 \mathrm{~m})$, including the buffering space.

\subsection{Crop Sampling}

The following crops were considered in the experiment: Open batavia lettuce (Lactuca sativa $\mathrm{L}$. Acephala Group), butterhead lettuce (Lactuca sativa L. Capitata Group), cauliflower (Brassica oleracea L. Botrytis Group), red chicory (Cichorium intybus L. var. foliosum Hegi), potato (Solanum tuberosum L.), Swiss chard (Beta vulgaris L. var. vulgaris), tomato (Lycopersicon esculentum Mill), and melon (Cucumis melo L. subsp. melo). For each plot, a sampling area $10 \mathrm{~m}^{2}$ wide was considered for plant assessment; this sampling area was randomly selected and harvested at crop marketable stage. Total fresh weight and marketable fresh weight were measured for each crop. One subsample (consisting of approximately one kilogram of marketable product and one kilogram of waste biomass) was used to measure dry weight and then total Kjeldahl nitrogen (TKN). Harvesting dates for all crops are reported in Table 3.

\subsection{Nitrogen Use Efficiency}

$\mathrm{N}$ harvest index (NHI) was calculated using the following equations:

$\mathrm{NHI}=\mathrm{N}$ uptake in marketable dry biomass/N uptake in total dry biomass.

NUE was evaluated using the approach suggested by Fageria et al. [31] calculating: Agronomic efficiency (AE), physiological efficiency (PE), and apparent recovery efficiency (ARE). Nitrogen indexes were calculated using the following equations: 


$$
\mathrm{AE}\left(\mathrm{mg} \mathrm{mg}^{-1}\right)=\mathrm{Gf}-\mathrm{Gu} / \mathrm{Na}
$$

$\mathrm{PE}\left(\mathrm{mg} \mathrm{mg}^{-1}\right)=\mathrm{BYf}-\mathrm{BYu} / \mathrm{Nf}-\mathrm{Nu}$

$$
\operatorname{ARE}(\%)=(\mathrm{Nf}-\mathrm{Nu} / \mathrm{Na}) \times 100
$$

where Gf is the marketable yield of the DADRs-fertilized plots $(\mathrm{kg}), \mathrm{Gu}$ is the marketable yield of the mineral-fertilized plots $(\mathrm{kg}), \mathrm{Na}$ is the quantity of $\mathrm{N}$ applied $(\mathrm{kg}), \mathrm{BYf}$ is the biological yield (total biomass) of the DADRs-fertilized plots (kg), BYu is the biological yield of the unfertilized plots (kg), Nf is the $\mathrm{N}$ uptake (total biomass) of the DADRs-fertilized plots, and $\mathrm{Nu}$ is the $\mathrm{N}$ uptake (total biomass) of the unfertilized plots $(\mathrm{kg})$.

\subsection{Statistical Analysis}

Analysis of variance (ANOVA) was used to evaluate treatment effect for each individual response variable. As there was no need to compare the two crop successions, the ANOVA was performed separately for the successions using a randomized block experimental design where the fertilization treatments were repeated in different parts of the field and treated as blocks. When treatment effect was significant, multiple Tukey comparisons were performed.

Table 2. Chemical properties of distillery anaerobic digestion residues (DADRs) used for the experiment

\begin{tabular}{|c|c|c|c|c|}
\hline \multirow{2}{*}{ Parameters } & & \multicolumn{2}{|c|}{ DADRs } & \multirow{2}{*}{ Methods } \\
\hline & & Water Extract & Ash Content & \\
\hline $\mathrm{pH}$ & & \multicolumn{2}{|c|}{7.68} & EN13037 \\
\hline Electrical conductivity & $\mu \mathrm{S} \mathrm{cm} \mathrm{cm}^{-1}$ & \multicolumn{2}{|c|}{1.462} & EN13038 \\
\hline Total organic matter & $\%$ & \multicolumn{2}{|c|}{49.94} & EN13039 \\
\hline Total organic carbon & $\%$ & \multicolumn{2}{|c|}{28.97} & [32] \\
\hline Total N & $\%$ & \multicolumn{2}{|c|}{3.48} & ISO1656 \\
\hline $\mathrm{C}: \mathrm{N}$ & & \multicolumn{2}{|c|}{8.32} & \\
\hline Ash & $\%$ & \multicolumn{2}{|c|}{50.06} & \\
\hline Dry matter & $\%$ & \multicolumn{2}{|c|}{30.21} & EN13040 \\
\hline $\mathrm{P}$ & $\mathrm{mg} \mathrm{kg}^{-1}$ & 42.6 & 5824 & \\
\hline K & $\mathrm{mg} \mathrm{kg}^{-1}$ & 1942 & 3044 & \\
\hline $\mathrm{Ca}$ & $\mathrm{mg} \mathrm{kg}^{-1}$ & 134 & 19189 & \\
\hline $\mathrm{Mg}$ & $\mathrm{mg} \mathrm{kg}^{-1}$ & 14.7 & 941 & \\
\hline $\mathrm{Mn}$ & $\mathrm{mg} \mathrm{kg}^{-1}$ & 0.038 & 63.7 & \\
\hline $\mathrm{Al}$ & $\mathrm{mg} \mathrm{kg}^{-1}$ & 0.363 & 3125 & \\
\hline $\mathrm{Fe}$ & $\mathrm{mg} \mathrm{kg}^{-1}$ & 0.238 & 1659 & \\
\hline $\mathrm{Na}$ & $\mathrm{mg} \mathrm{kg}^{-1}$ & 126 & 2039 & \\
\hline Co & $\mathrm{mg} \mathrm{kg}^{-1}$ & 0.006 & 0.42 & \\
\hline $\mathrm{Cd}$ & $\mathrm{mg} \mathrm{kg}^{-1}$ & nd & nd & \\
\hline $\mathrm{Cr}$ & $\mathrm{mg} \mathrm{kg}^{-1}$ & 0.006 & 6.72 & \\
\hline $\mathrm{Cu}$ & $\mathrm{mg} \mathrm{kg}^{-1}$ & 0.371 & 488 & \\
\hline $\mathrm{Pb}$ & $\mathrm{mg} \mathrm{kg}^{-1}$ & nd & 1.81 & [33] \\
\hline $\mathrm{Ni}$ & $\mathrm{mg} \mathrm{kg}^{-1}$ & 0.054 & 3.96 & \\
\hline $\mathrm{Zn}$ & $\mathrm{mg} \mathrm{kg}^{-1}$ & 0.904 & 56.8 & \\
\hline As & $\mathrm{mg} \mathrm{kg}^{-1}$ & 0.038 & 0.75 & \\
\hline $\mathrm{B}$ & $\mathrm{mg} \mathrm{kg}^{-1}$ & 4.11 & 64.6 & \\
\hline $\mathrm{Li}$ & $\mathrm{mg} \mathrm{kg}^{-1}$ & 0.665 & 6.79 & \\
\hline Mo & $\mathrm{mg} \mathrm{kg}^{-1}$ & 0.018 & 0.60 & \\
\hline$S$ & $\mathrm{mg} \mathrm{kg}^{-1}$ & 72.3 & 1509 & \\
\hline $\mathrm{Sb}$ & $\mathrm{mg} \mathrm{kg}^{-1}$ & 0.031 & 0.25 & \\
\hline Se & $\mathrm{mg} \mathrm{kg}^{-1}$ & 0.031 & 0.25 & \\
\hline Sn & $\mathrm{mg} \mathrm{kg}^{-1}$ & 0.018 & 1.73 & \\
\hline $\mathrm{Sr}$ & $\mathrm{mg} \mathrm{kg}^{-1}$ & 0.542 & 56.4 & \\
\hline $\mathrm{Ti}$ & $\mathrm{mg} \mathrm{kg}^{-1}$ & 0.006 & 23.3 & \\
\hline V & $\mathrm{mg} \mathrm{kg}^{-1}$ & 0.012 & 3.97 & \\
\hline
\end{tabular}
on a dry matter basis.

nd: Not detected; *: (ICP-AES) SPECTRO Ciros (Spectro Srl, Kleve, Italy). 
Table 3. Five-year crop successions using DADRs: Varieties, sowing and harvesting dates, plant spacing, densities, mineral, and 100\% DADRs fertilization supplied.

\begin{tabular}{|c|c|c|c|c|c|c|c|c|c|c|}
\hline Year & Season & Crop & Variety & $\begin{array}{r}\text { Date of } \\
\text { Sowing/Transplant }\end{array}$ & Harvest & $\begin{array}{l}\text { Spacing } \\
\text { Rows (m) }\end{array}$ & $\begin{array}{l}\text { between: } \\
\text { Plants (m) }\end{array}$ & $\begin{array}{c}\text { Density } \\
\left.\text { (Plant } \mathrm{m}^{-2}\right)\end{array}$ & $\begin{array}{c}\text { Mineral } \mathrm{N}_{-} \mathrm{P}_{2} \mathrm{O}_{5}-\mathrm{K}_{2} \mathrm{O} \\
\text { Fertilization (TMIN) } \mathrm{kg} \mathrm{ha}^{-1}\left(^{*}\right)\end{array}$ & $\begin{array}{l}\text { 100\% DADRs Fertilization } \\
\text { (T100) } \mathrm{kg} \mathrm{ha}^{-1}\end{array}$ \\
\hline \multicolumn{11}{|c|}{ Succession 1} \\
\hline \multirow[b]{2}{*}{1 st } & spring-summer & batavia lettuce & Funtine & May 11 & June 18 & 0.50 & 0.33 & 6.1 & $80-60-110$ & 7662 \\
\hline & fall-winter & late cauliflower & Atalaya & Aug 10 & Dec 2 & 0.65 & 0.50 & 3.1 & $100-60-160$ & 9578 \\
\hline \multirow{2}{*}{ 2nd } & spring-summer & $\begin{array}{l}\text { butter-head } \\
\text { lettuce }\end{array}$ & Pronto & June 30 & Aug 11 & 0.40 & 0.30 & 8.5 & $80-60-110$ & 7662 \\
\hline & fall-winter & early chicory & Adige precoce & Aug 27 & Nov 24 & 0.40 & 0.30 & 8.5 & $130-60-180$ & 12452 \\
\hline \multirow{2}{*}{$3 \mathrm{rd}$} & spring-summer & potato & Etna & April 5 & July 18 & 0.65 & 0.25 & 6.2 & $180-100-200$ & 17241 \\
\hline & fall-winter & Swiss chards & White silver & Aug 23 & Nov 2 & 0.45 & 0.35 & 6.3 & $120-150-160$ & 11494 \\
\hline 4th & spring-summer & tomato & Perfect Peel & May 15 & Aug 23 & 0.50 & 0.50 & 4.0 & $130-100-200$ & 12452 \\
\hline 5 th & spring-summer & melon & Macigno & June 11 & Aug 17 & 1.60 & 0.80 & 0.8 & $150-100-200$ & 14367 \\
\hline \multicolumn{11}{|c|}{ Succession 2} \\
\hline \multirow[t]{2}{*}{1 st } & spring-summer & $\begin{array}{l}\text { butter-head } \\
\text { lettuce }\end{array}$ & Marenia & April 10 & May 25 & 0.50 & 0.33 & 6.1 & $80-60-110$ & 7662 \\
\hline & fall-winter & $\begin{array}{c}\text { early } \\
\text { cauliflower }\end{array}$ & Freemont & Aug 10 & Nov 11 & 0.65 & 0.50 & 3.1 & $100-60-160$ & 9578 \\
\hline \multirow{2}{*}{ 2nd } & spring-summer & iceberg lettuce & Silvinas & June 30 & Aug 11 & 0.40 & 0.30 & 8.5 & $80-60-110$ & 7662 \\
\hline & fall-winter & late radicchio & Adige tardivo & Aug 27 & Jan 13 & 0.40 & 0.30 & 8.5 & $130-60-180$ & 12452 \\
\hline \multirow{2}{*}{$3 r d$} & spring-summer & potato & Etna & April 5 & July 18 & 0.65 & 0.25 & 6.2 & $180-100-200$ & 17241 \\
\hline & fall-winter & chicory & Romea & Aug 23 & Nov 17 & 0.45 & 0.35 & 6.3 & $120-150-160$ & 11494 \\
\hline 4th & spring-summer & pepper & Pompeo & May 15 & Aug 1-28 & 0.50 & 0.50 & 4.0 & $130-100-200$ & 12452 \\
\hline 5 th & spring-summer & melon & Macigno & June 11 & Aug 17 & 1.60 & 0.80 & 0.8 & $150-100-200$ & 14367 \\
\hline
\end{tabular}

${ }^{*}$ Mineral NPK fertilization used: Urea $(46 \% \mathrm{~N})$, triple superphosfate $\left(46 \% \mathrm{P}_{2} \mathrm{O}_{5}\right)$, and potassium sulphate $\left(50 \% \mathrm{~K}_{2} \mathrm{O}\right)$. 


\section{Results}

\subsection{Distillery Anaerobic Digestion Residues}

Table 2 reports the chemical characteristics of the DADRs used in the experiment and showed $49.94 \%$ of total organic matter contents (TOM) and $28.97 \%$ of total organic carbon contents (TOC). This material presented a high nutrients content ( $\mathrm{N}, \mathrm{P}$ and $\mathrm{K})$, supporting the idea of a highly nutritive by-product. At the same time, it showed a low $\mathrm{C}: \mathrm{N}$ ratio (8.32) and the heavy metal content $(\mathrm{Cr}, \mathrm{Pb}, \mathrm{Cd}$, and $\mathrm{Zn}$ ) was below the limits specified by the European Union for digestates used as soil enhancers (The Commission of the European Communities, 2006). DADRs were rather basic or alkaline with a $\mathrm{pH}$ value of 7.68. Lastly, electrical conductivity (EC) was high $\left(1.46 \mathrm{mS} \cdot \mathrm{cm}^{-1}\right)$ due to the high content of salts in this material.

\subsection{Production-Succession 1}

In succession 1, treatment $\mathrm{T} 75$ produced the highest marketable yield and total biomass for batavia lettuce in the 1st year (Table 4), though not significantly different from TMIN, T50, and T100.

Table 4. Yield and total biomass produced by each crop within two successions.

\begin{tabular}{|c|c|c|c|c|c|c|c|c|}
\hline \multicolumn{9}{|c|}{ Succession 1 (S1) } \\
\hline & $\begin{array}{l}\text { Batavia } \\
\text { Lettuce }\end{array}$ & $\begin{array}{c}\text { Late } \\
\text { Cauliflower }\end{array}$ & $\begin{array}{l}\text { Butter-Head } \\
\text { Lettuce }\end{array}$ & $\begin{array}{c}\text { Early } \\
\text { Chicory }\end{array}$ & Potato & $\begin{array}{l}\text { Swiss } \\
\text { Chard }\end{array}$ & Tomato & Melon \\
\hline \multicolumn{9}{|c|}{ Yield $\left(\mathrm{t} \mathrm{ha}^{-1} \mathrm{fw}\right)$} \\
\hline T0 & $8.2 \mathrm{~b}$ & $11.3 \mathrm{c}$ & $11.9 \mathrm{~b}$ & $18.3 \mathrm{~b}$ & 33.1 & $34.3 \mathrm{~b}$ & $54.3 \mathrm{~b}$ & $19.3 \mathrm{~b}$ \\
\hline TMIN & $13.2 \mathrm{ab}$ & $17.3 \mathrm{~b}$ & $15.4 \mathrm{a}$ & $27.8 \mathrm{a}$ & 35.1 & $47.9 \mathrm{a}$ & $69.9 \mathrm{ab}$ & 39.9 a \\
\hline $\mathrm{T} 50$ & $13.2 \mathrm{ab}$ & $17.3 \mathrm{~b}$ & $14.3 \mathrm{a}$ & $23.5 \mathrm{ab}$ & 33.2 & $40.2 \mathrm{ab}$ & $68.6 \mathrm{ab}$ & $39.4 \mathrm{a}$ \\
\hline T75 & $17.7 \mathrm{a}$ & $14.2 \mathrm{bc}$ & $14.0 \mathrm{ab}$ & $23.7 \mathrm{ab}$ & 37.4 & $39.4 \mathrm{ab}$ & $75.4 \mathrm{a}$ & $29.9 \mathrm{ab}$ \\
\hline $\mathrm{T} 100$ & $12.7 \mathrm{ab}$ & $23.4 \mathrm{a}$ & $14.8 \mathrm{a}$ & $20.0 \mathrm{~b}$ & 35.3 & $41.2 \mathrm{ab}$ & $84.1 \mathrm{a}$ & $31.8 \mathrm{ab}$ \\
\hline \multicolumn{9}{|c|}{ Total biomass ( $\left.\mathrm{t} \mathrm{ha}^{-1} \mathrm{fw}\right)$} \\
\hline T0 & $10.4 \mathrm{~b}$ & $47.4 \mathrm{~b}$ & $15.0 \mathrm{~b}$ & $28.8 \mathrm{c}$ & 39.3 & 51.3 & $87.7 \mathrm{~d}$ & $34.5 \mathrm{~b}$ \\
\hline TMIN & $16.2 \mathrm{ab}$ & $73.6 \mathrm{a}$ & $19.1 \mathrm{a}$ & $50.6 \mathrm{a}$ & 44.4 & 61.9 & $100.7 \mathrm{~cd}$ & $59.9 \mathrm{a}$ \\
\hline T50 & $16.0 \mathrm{ab}$ & $69.1 \mathrm{a}$ & $17.5 \mathrm{ab}$ & $37.4 \mathrm{bc}$ & 45.6 & 59.8 & $137.1 \mathrm{~b}$ & $60.7 \mathrm{a}$ \\
\hline $\mathrm{T} 75$ & $21.1 \mathrm{a}$ & $70.1 \mathrm{a}$ & $18.4 \mathrm{a}$ & $40.1 \mathrm{ab}$ & 45.0 & 52.5 & $119.0 \mathrm{bc}$ & $52.0 \mathrm{ab}$ \\
\hline T100 & $16.0 \mathrm{ab}$ & $64.9 \mathrm{a}$ & $18.1 \mathrm{a}$ & $30.9 \mathrm{bc}$ & 41.0 & 58.5 & $172.3 \mathrm{a}$ & $50.7 \mathrm{ab}$ \\
\hline \multicolumn{9}{|c|}{ Succession 2 (S2) } \\
\hline & $\begin{array}{l}\text { butter-head } \\
\text { lettuce }\end{array}$ & $\begin{array}{c}\text { early } \\
\text { cauliflower }\end{array}$ & $\begin{array}{l}\text { iceberg } \\
\text { lettuce }\end{array}$ & $\begin{array}{c}\text { late } \\
\text { chicory }\end{array}$ & potato & $\begin{array}{l}\text { catalogna } \\
\text { chicory }\end{array}$ & $\begin{array}{l}\text { sweet } \\
\text { pepper }\end{array}$ & melon \\
\hline \multicolumn{9}{|c|}{ Yield (t ha $\left.{ }^{-1} \mathrm{fw}\right)$} \\
\hline T0 & $9.5 \mathrm{~b}$ & $15.4 \mathrm{~b}$ & $13.8 \mathrm{~b}$ & $11.6 \mathrm{c}$ & 31.9 & $31.1 \mathrm{~b}$ & 17.6 & $21.3 c$ \\
\hline TMIN & $16.3 \mathrm{a}$ & $28.1 \mathrm{a}$ & $23.0 \mathrm{a}$ & $22.3 \mathrm{a}$ & 35.5 & $46.8 \mathrm{a}$ & 24.1 & $35.2 \mathrm{~b}$ \\
\hline $\mathrm{T} 50$ & $12.4 \mathrm{ab}$ & $24.5 \mathrm{ab}$ & $20.4 \mathrm{a}$ & $16.7 \mathrm{~b}$ & 33.0 & $34.3 \mathrm{~b}$ & 17.5 & $41.5 \mathrm{a}$ \\
\hline $\mathrm{T} 75$ & $13.2 \mathrm{ab}$ & $22.4 \mathrm{ab}$ & $21.8 \mathrm{a}$ & $20.2 \mathrm{a}$ & 33.1 & $37.9 \mathrm{~b}$ & 24.8 & $33.2 \mathrm{~b}$ \\
\hline T100 & $10.1 \mathrm{~b}$ & $18.3 \mathrm{ab}$ & $18.4 \mathrm{ab}$ & $16.1 \mathrm{~b}$ & 35.6 & $34.7 \mathrm{~b}$ & 21.7 & $35.2 \mathrm{~b}$ \\
\hline \multicolumn{9}{|c|}{ Total biomass $\left(\mathrm{t} \mathrm{ha}^{-1} \mathrm{fw}\right)$} \\
\hline T0 & $14.2 \mathrm{~b}$ & $49.4 \mathrm{~b}$ & $17.8 \mathrm{~b}$ & $21.0 \mathrm{~b}$ & 39.8 & $39.2 \mathrm{c}$ & 37.3 & $40.8 \mathrm{~b}$ \\
\hline TMIN & $23.5 \mathrm{a}$ & $78.9 \mathrm{a}$ & $28.7 \mathrm{a}$ & $59.8 \mathrm{a}$ & 46.4 & $48.9 \mathrm{a}$ & 51.0 & $57.6 \mathrm{a}$ \\
\hline T50 & $18.1 \mathrm{ab}$ & $66.8 \mathrm{ab}$ & $24.2 \mathrm{ab}$ & $37.4 \mathrm{~b}$ & 41.8 & $40.3 \mathrm{bc}$ & 39.3 & $48.8 \mathrm{ab}$ \\
\hline T75 & $19.0 \mathrm{ab}$ & $57.8 \mathrm{ab}$ & $28.5 \mathrm{a}$ & 56.9 a & 42.6 & $46.1 \mathrm{ab}$ & 49.8 & $48.9 \mathrm{ab}$ \\
\hline T100 & $14.5 \mathrm{~b}$ & $52.3 \mathrm{ab}$ & $25.0 \mathrm{ab}$ & $27.2 \mathrm{~b}$ & 44.3 & $41.6 \mathrm{bc}$ & 48.0 & $57.2 \mathrm{ab}$ \\
\hline
\end{tabular}

Within each parameter, values without common letters significantly differ at $p<0.05$ according to HSD Tukey Test.

The lowest yield was obtained in the unfertilized control (T0). The following crop, late cauliflower, showed highest production with completely organic fertilization (T100), 35.3\% higher than TMIN, and $102 \%$ higher than T0. When considering total biomass, no differences were detected among the fertilized treatments, which where all higher than T0. Also in the third crop, butterhead lettuce yield was found to be higher for all fertilized treatments, with no significant differences among them. 
Similarly, total biomass was alike among treatments, with values ranging from $17.5 \mathrm{t} \mathrm{ha}^{-1}$ to $19.1 \mathrm{tha}^{-1}$ for fertilized treatments. During the autumn of the 2nd year, early chicory plants displayed a better use of mineral fertilization compared to the organic one or the T0, resulting in a yield increment of more than $7 \mathrm{t} \mathrm{ha}^{-1}$. This outcome can be related to the high total biomass production recorded for TMIN, over $50 \mathrm{t} \mathrm{ha}^{-1}$, indicating an increase of $63.7 \%$. For potato, no effect of the fertilization treatment was observed. Conversely, Swiss chard yield was found to be significantly higher in conventionally fertilized plots, compared to T0. The other treatments were not statistically different, as also noted for total biomass among all treatments. For tomato marketable yield, T100 and T75 treatments were the most productive, and not statistically different from T50 and TMIN. Total biomass showed a remarkable high production for T100 (about $170 \mathrm{t} \mathrm{ha}^{-1}$ ); T75 and T50 yield lay between 140 and $120 \mathrm{t} \mathrm{ha}^{-1}$, TMIN was around $100 \mathrm{t} \mathrm{ha}^{-1}$, and T0 below $90 \mathrm{tha}^{-1}$. For melon, both marketable yield and total biomass were the lowest in the unfertilized plots, but only in TMIN and T50 values were significantly higher (+105\% and $74.8 \%$, respectively).

\subsection{Production-Succession 2}

Butterhead lettuce showed no difference between the unfertilized treatment and T100, in both marketable yield and total biomass, and TMIN was the most productive treatment. In regards to total biomass production in particular, TMIN showed the highest value with $23.5 \mathrm{t} \mathrm{ha}^{-1}$, although this yield included a considerable amount of discarded material (+63.6\% compared to T100). Early cauliflower marketable yield revealed a better performance of TMIN, which was progressively lower when increasing DADRs were used, although not significantly. Total biomass gave similar results among treatments, and the waste share was reduced when reducing the mineral fertilizer. The following crop, spring iceberg lettuce, displayed, as expected, the lowest yield in T0, and no differences were observed among the others. A similar trend was presented by total biomass. In the autumn of the 2nd year, late chicory showed higher marketable and total biomass for TMIN and T75, almost double that of T0; T100 and T50 had similar and intermediate values. Potato showed, similarly to succession 1, no difference among treatments. Conversely, in catalogna chicory, mineral fertilization increased yield by $50.5 \%$ compared with the unfertilized control, whereas the other treatments gave similar results to T0. Concerning total biomass, TMIN and T75 showed the highest values, T100 and T50 were comparable with lower values, T0 was the lowest with only $39.2 \mathrm{t} \mathrm{ha}^{-1}$. No effect of the fertilization treatment was found on yield and total biomass production of pepper. At last, for melon the highest yield was obtained in T50, and was significantly lower in all the other treatments, in particular compared to T0. The crop total biomass was higher in TMIN than in T0, but not different from the other fertilized treatments.

\subsection{Nitrogen Crops Uptake}

For both crop rotations, $\mathrm{N}$ uptake by individual crops was measured. $\mathrm{N}$ was calculated in crop production based on marketable production (Figure 2) and on crop residues (Figure 3). For this reason, the amount of fertilizer applied refers to the usual standard practice of the area [23]. The soil where the experiment was located had a limited amount of organic matter $(<1.1 \%)$ and, consequently, fertilizer management did not consider the soil nutrients stock as a consequence of the crop successions.

In both crop rotations, a total amount of $970 \mathrm{~N}$ units were distributed during the 5 years of the experiment. Crop succession 1 was able to sequester an amount of $\mathrm{N}$ ranging from 400 to $500 \mathrm{~kg} \mathrm{ha}^{-1}$ (Figure 2). The T0 treatment had the lower level (about $400 \mathrm{~kg} \mathrm{ha}^{-1}$ of N), T50 and T75, with approximately $450 \mathrm{~N}$ units, were the intermediate values, and finally TMIN and T100 had the highest uptake (about $500 \mathrm{~kg} \mathrm{ha}^{-1}$ of $\mathrm{N}$ ). Cumulative uptake for marketable yield for S2, even if it received the same amount of $\mathrm{N}$, was remarkably lower than for S1 (300-400 kg ha ${ }^{-1}$ of N). Furthermore, the highest uptake was recorded for TMIN ( $395 \mathrm{~kg} \mathrm{ha}^{-1} \mathrm{~N}$ ), followed by T100, and then by T0; T75 and T50 showed no difference either with T100, or with T0. When observing the two crop successions up to the potato crop entering the rotation, $\mathrm{N}$ uptakes were quite similar, and ranged from about 150 to 
$200 \mathrm{~kg} \mathrm{ha}^{-1}$ of N. Then, a sharp change was observed: The Swiss chard crop was very effective in increasing cumulated $\mathrm{N}$ uptake ( $+69.5 \%$, on average), whereas, in S2, catalogna chicory, despite being also a leaf crop with minimal residues, had limited $\mathrm{N}$ uptake. Other than this, the following crops in $\mathrm{S} 1$ (mainly tomato) were capable of removing additional and relevant amounts of $\mathrm{N}$ in marketable yield. In S2, pepper, severely damaged by a hail event, was unable to recover and had an overall poor production: As a consequence, the amount of $\mathrm{N}$ uptake by the fruits was low. Similar results were shown by melon, displaying comparable $\mathrm{N}$ uptake in both rotations.

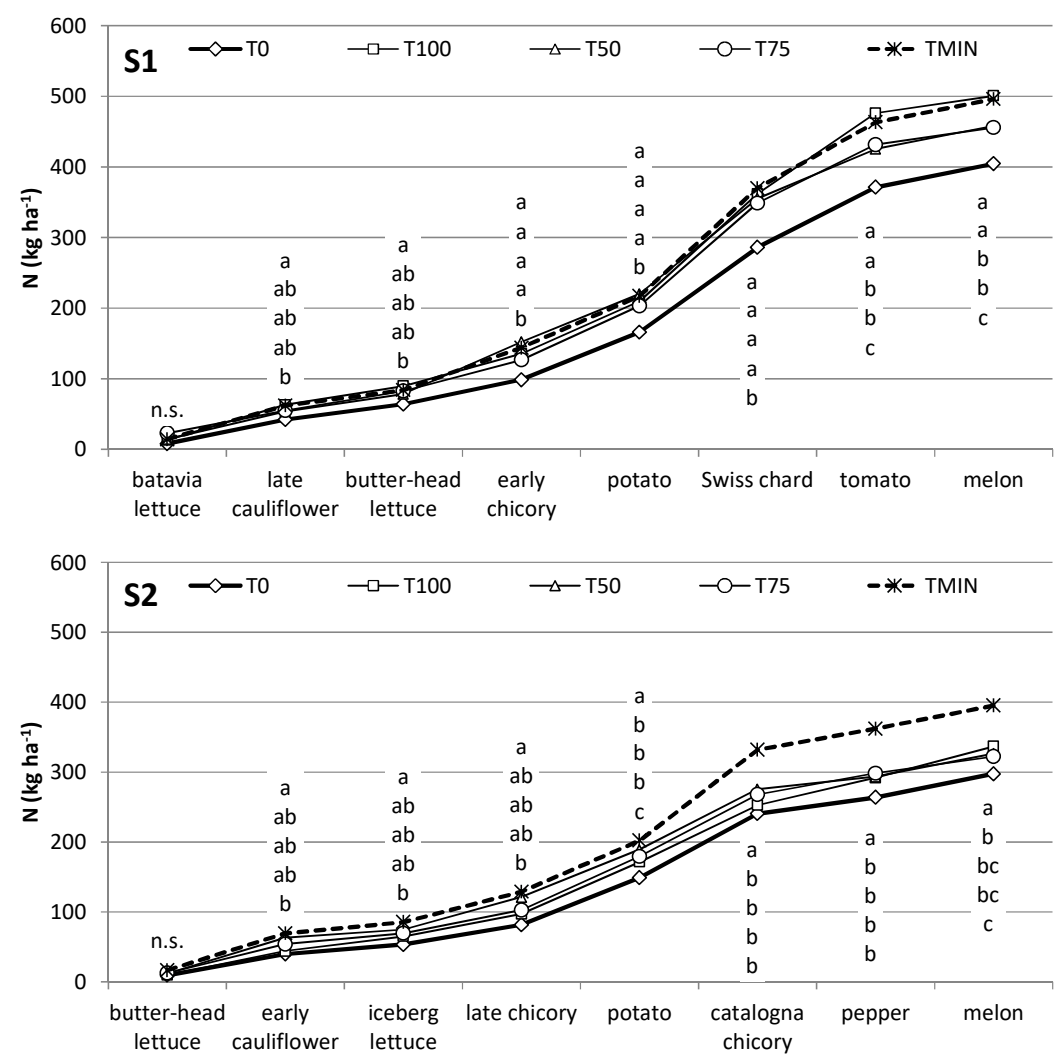

Figure 2. Cumulated nitrogen uptake of marketable production during S1 (a) and S2 (b) crop successions according to fertilization treatments. Within each crop, values without common letters significantly differ at $p<0.05$, according to HSD Tukey Test. n.s.: Not significant. T50: 50\% N through DADRs and $50 \% \mathrm{~N}$ through mineral fertilizer; T75: 75\% $\mathrm{N}$ through DADRs and 25\% $\mathrm{N}$ through mineral fertilizer; T100: 100\% N through DADRs; T0: unfertilized control; TMIN: mineral control.

To underline the potential efficiency of each rotation in intercepting the global amount of $\mathrm{N}$ distributed, it was noticed that TMIN and T100 in S1 showed the highest values with $51.2 \%$, while T50 and T75 were only about $47 \%$. Among fertilization treatments, T0 as expected, displayed the lowest performance in terms of $\mathrm{N}$ uptake. However, crops in $\mathrm{T} 0$ were able to remove $404 \mathrm{~kg} \mathrm{ha}^{-1}$ and $297 \mathrm{~kg} \mathrm{ha}^{-1}$ of N, respectively, for S1 and S2, even if no N was provided through fertilization. Such results underline the high initial fertility of the soil where the experiment was carried out: 3-4 years of cultivation were necessary to obtain a significant difference in $\mathrm{N}$ uptake between $\mathrm{T} 0$ and all the other treatments.

In contrast with that recorded for effective $\mathrm{N}$ removed by marketable yield, the two crop successions provided more similar results in terms of $\mathrm{N}$ uptake by crop residues (Figure 3). In both successions, the maximum amount of $\mathrm{N}$ remaining in the field in crop residues was approximately $450 \mathrm{~kg} \mathrm{ha}^{-1}$, whereas the lowest amount was quite different in the two successions (275 and $345 \mathrm{~kg} \mathrm{ha}^{-1}$ in S1 and S2, respectively). Significant differences were found among treatments: In S1, TMIN and T75 showed the highest amount of $\mathrm{N}$ in crop residues, whereas in $\mathrm{S} 2$ the highest values were found with TMIN 
only; then, a similar trend was observed between S1 and S2: The higher the amount of mineral fertilizer distributed, the higher the $\mathrm{N}$ uptake in crop residues. In contrast, T100 gave similar results to TMIN in $\mathrm{S} 1$, and had the lower amount of $\mathrm{N}$ in the residues within the fertilized treatments $(-14.8 \%)$.

In relation to the contribution of the single crop on the global amount of $\mathrm{N}$ in crop residues, in both rotations a sharp increase was shown according to the final two chosen crops. In S1, tomato and melon, known for high above ground biomass, showed a global average increase of above $50 \%$ compared to Swiss chard. In S2, pepper and melon showed similar results, with an increase of cumulated $\mathrm{N}$ higher than $40.3 \%$ compared to catalogna chicory.

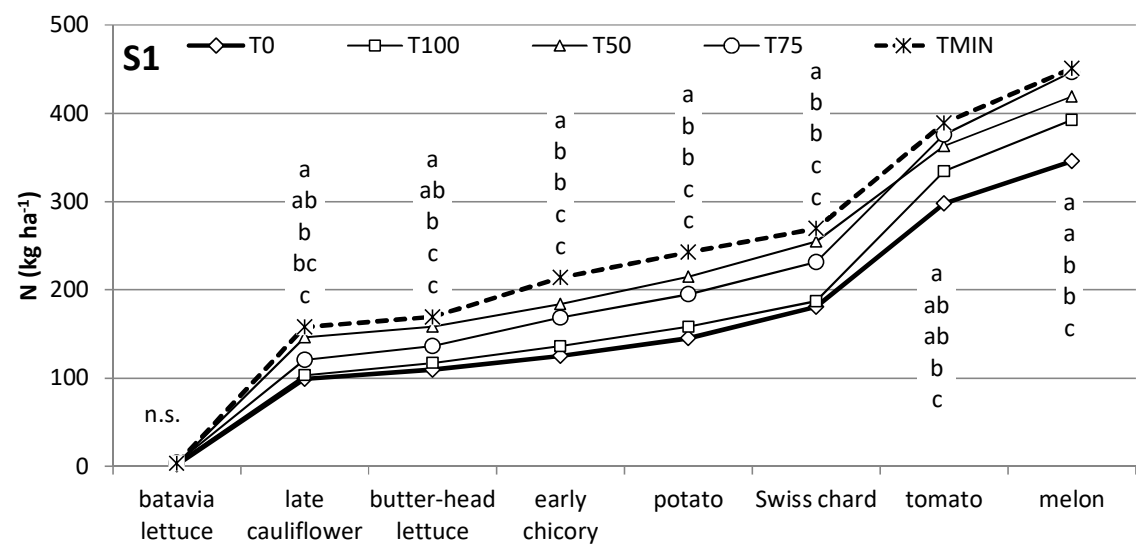

(a)

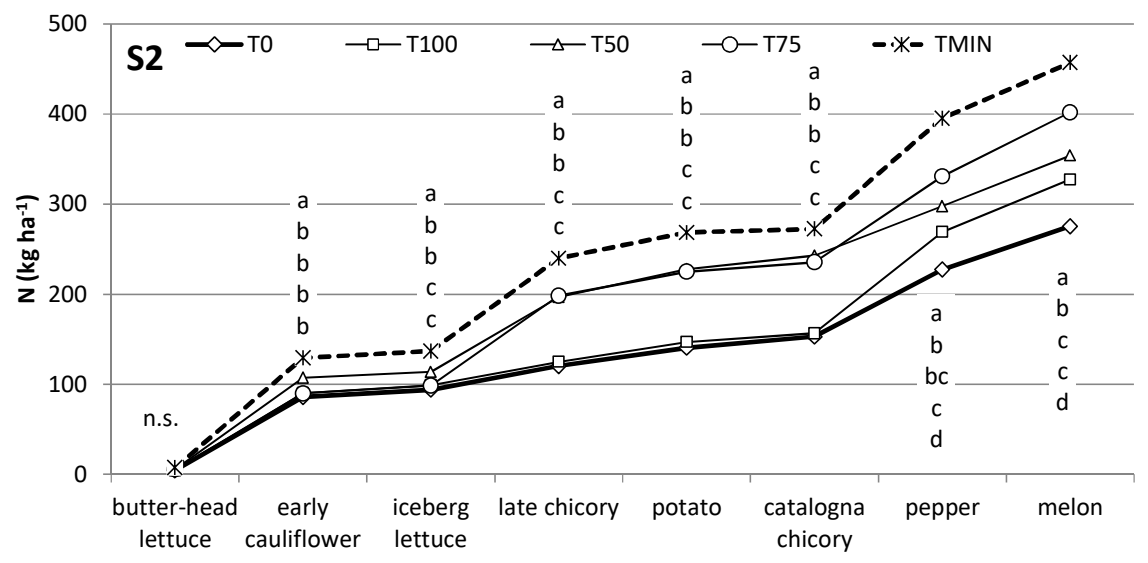

(b)

Figure 3. Cumulated nitrogen uptake in crop residues during S1 (a) and S2 (b) crop successions, according to fertilization treatments. Within each crop, values without common letters significantly differ at $p<0.05$, according to HSD Tukey Test. n.s.: Not significant. T50: 50\% N through DADRs and $50 \% \mathrm{~N}$ through mineral fertilizer; T75: 75\% N through DADRs and 25\% N through mineral fertilizer; T100: 100\% N through DADRs; T0: unfertilized control; TMIN: mineral control.

\section{5. $\mathrm{N}$ Harvest Index (NHI)}

As far as the $\mathrm{N}$ content in marketable product compared to the $\mathrm{N}$ content in the total biomass, data were reported after normalization on TMIN to illustrate crop and rotation response to the increasing DADR rates compared to the mineral fertilization.

The two rotations gave quite similar results (Figure 4). In both successions, only two crops showed significant differences in NHI: Late cauliflower and melon in S1, and late chicory and melon in S2. In both successions, in the first crop showing differences, T100 significantly increased NHI compared to TMIN ( $+53.6 \%$, and $+61.4 \%$, respectively), followed by T50 ( $+16.8 \%$ and $+20.3 \%$, respectively); T75 showed the least ability to accumulate $\mathrm{N}$ in the marketable production. Moreover, in both successions, $\mathrm{NHI}$ of melon progressively decreased along with the increase of DADR rates in the fertilization. 


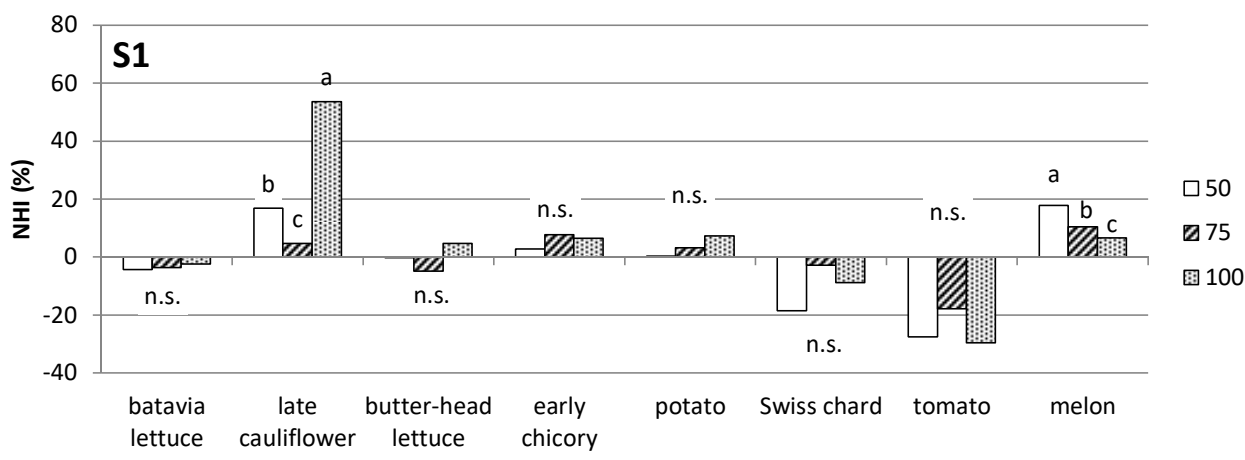

(a)

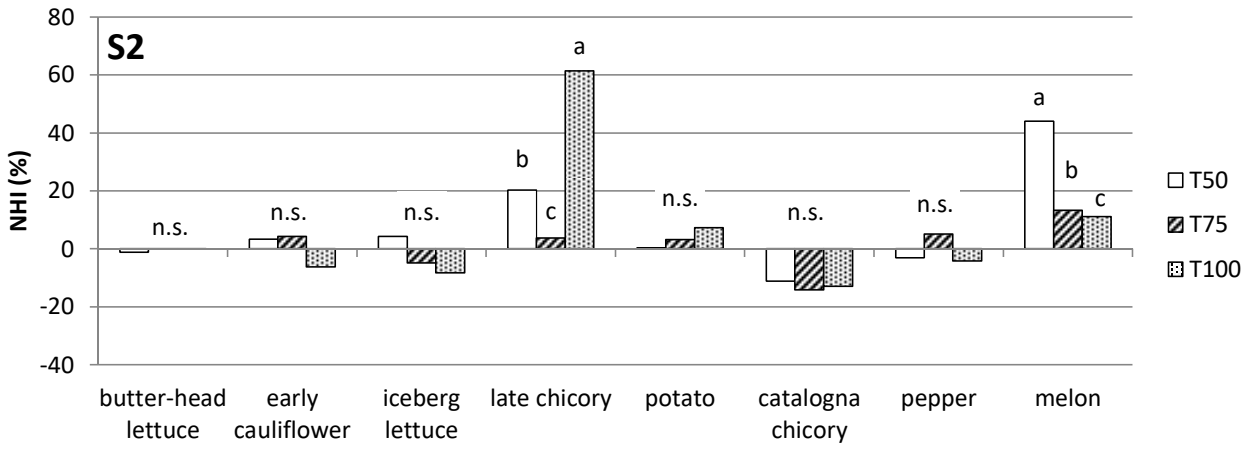

Figure 4. Nitrogen harvest index (NHI) normalized for mineral control (TMIN) during crop successions (S1 (a) and S2 (b)). Within each crop, values without common letters significantly differ at $p<0.05$, according to HSD Tukey Test. n.s.: Not significant. T50: 50\% N through DADRs and 50\% N through mineral fertilizer; T75: 75\% $\mathrm{N}$ through DADRs and 25\% $\mathrm{N}$ through mineral fertilizer; T100: 100\% $\mathrm{N}$ through DADRs.

\subsection{Nitrogen Use Efficiency}

Some indexes have been analyzed in order to evaluate $\mathrm{N}$ use efficiency, to assess crop ability to intercept nitrogen in relation to fertilization, and crop succession. To better clarify and explain the obtained results, it was decided to refer only to the opposite fertilization treatments: TMIN and T100. For S1 (Figure 5), AE, PE, and ARE did not differ for batavia lettuce and butterhead lettuce. The late cauliflower response was different: Both AE and PE were significantly higher in T100 than in TMIN, whereas ARE were very high in TMIN with over $96 \%$ of $N$ uptake for every unit of applied $\mathrm{N}$. As for the other leaf crops, but with a longer cycle, early chicory displayed reduced efficiency in $\mathrm{N}$ utilization in T100 compared to TMIN in all the indexes examined, with the highest difference between treatments in $\mathrm{AE}(-81.5 \%)$. In regards to potato, fertilization with the highest addition of DADRs showed a significant increase of AE and PE compared to mineral fertilization, whereas ARE did not differ. The results for Swiss chard, a leaf vegetable with summer-autumn growing season, showed that the crop did not benefit from T100: Indexes were $49.1 \%$ and $36.9 \%$ lower for AE and ARE, respectively. The opposite was found for tomato, whose AE and ARE were significantly improved by fertilization with DADRs. In regards to ARE, T100 reached $87.5 \%$, whereas TMIN was only $24.4 \%$. Finally, melon, the last crop, showed no difference in its response for both $\mathrm{AE}$ and $\mathrm{PE}$, whereas the apparent $\mathrm{N}$ recovery by melon crop was higher in TMIN, with $31.8 \%$.

Regarding the second crop succession (Figure 6), for the butterhead lettuce, AE and ARE were significantly higher in TMIN, in contrast to PE which did not show significant differences, reaching about $1000 \mathrm{~kg} \mathrm{~kg}^{-1}$. Higher AE and ARE were also recorded in TMIN for early cauliflower, iceberg lettuce, late chicory, and catalogna chicory. This last crop showed overall higher efficiency with $\mathrm{AE}$ exceeding $250 \mathrm{~kg} \mathrm{~kg}^{-1}$ and ARE around 80\%. For the remaining crops, no differences were recorded for $\mathrm{AE}$ or ARE and the registered values were particularly poor for potatoes, being lower than $20 \mathrm{~kg} \mathrm{~kg}^{-1}$ and $20 \%$, respectively. In relation to the PE, significant differences were observed for early cauliflower, 
iceberg lettuce, late chicory, and pepper. For the first two crops, TMIN provided the worst results, $79.0 \%$ and $72.1 \%$ lower than T100, respectively. For the pepper, PE was generally extremely low and, unlike the two crops mentioned above, TMIN had the highest value.

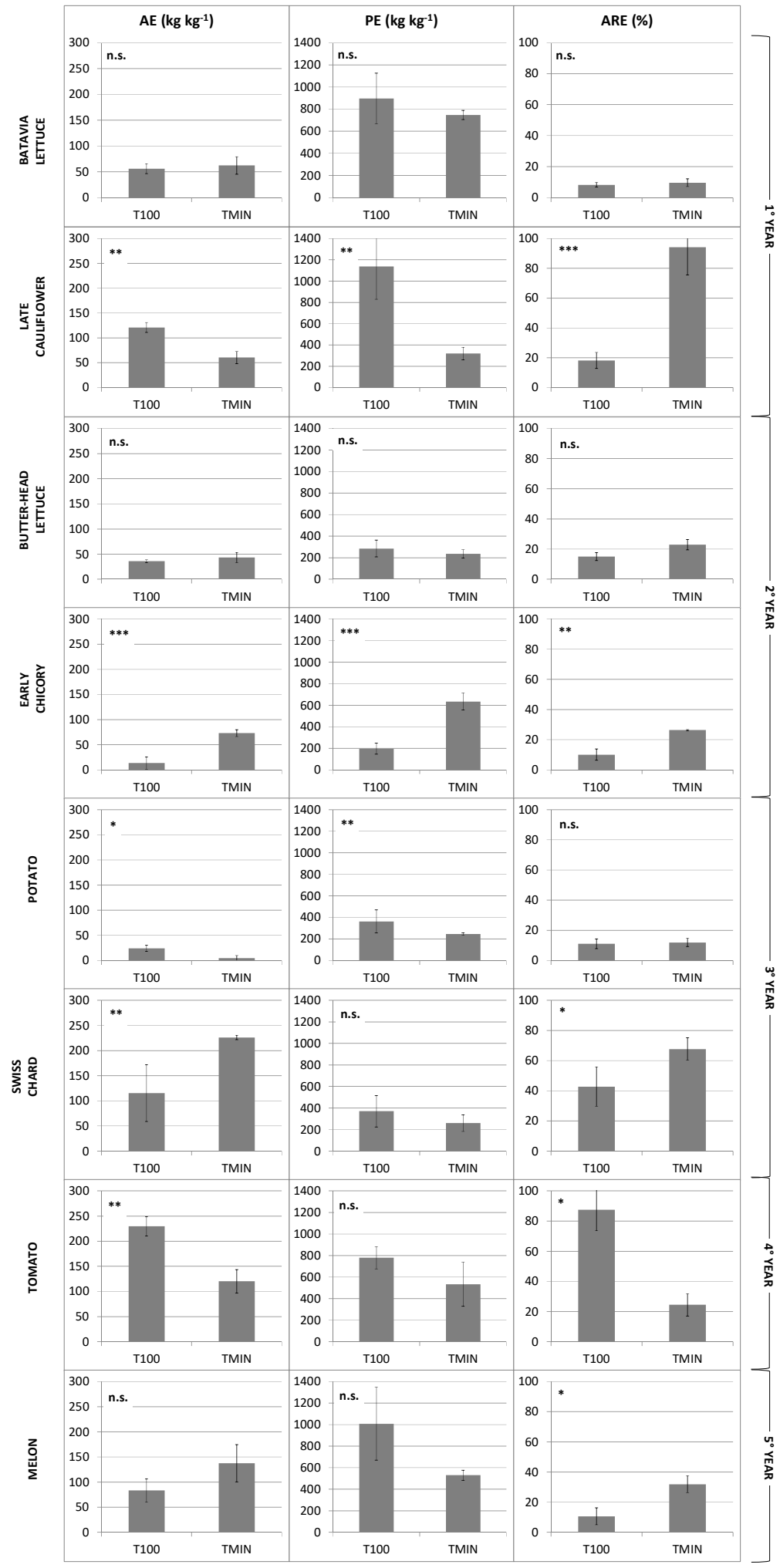

Figure 5. Nitrogen use efficiency indexes within the S1 crop succession. (AE: Agronomic efficiency; PE: Physiological efficiency; ARE: Apparent recovery efficiency). n.s.: Not significant; *: Significant $p<0.05$; **: Significant $p<0.01 ;{ }^{* * *}$ significant $p<0.001$. T100: 100\% N through DADRs; TMIN: Mineral control. 


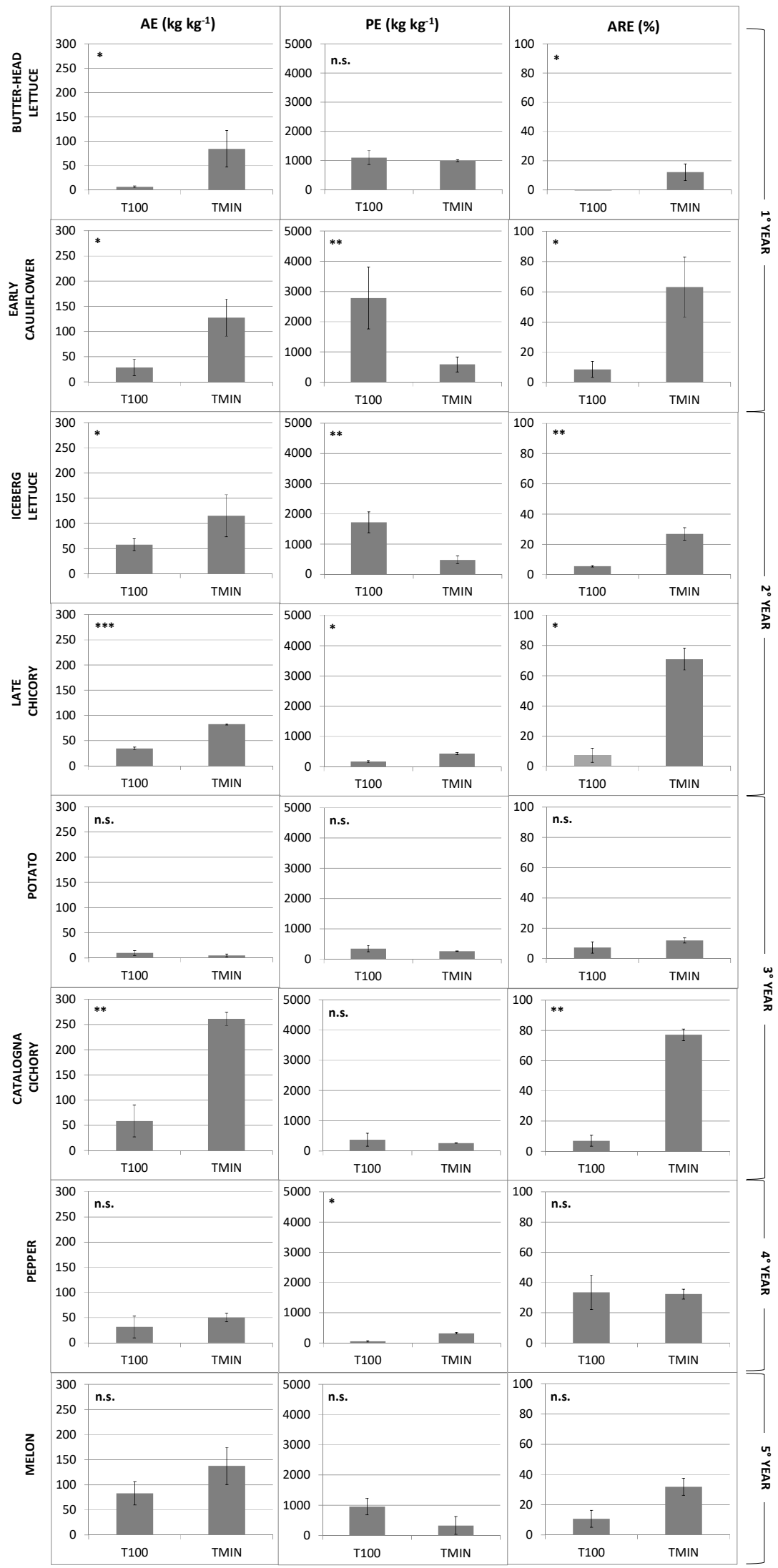

Figure 6. Nitrogen use efficiency indexes within the S2 crop succession. (AE: Agronomic efficiency; PE: Physiological efficiency; ARE: Apparent recovery efficiency). n.s.: Not significant; *: Significant $p<0.05$; **: Significant $p<0.01 ;{ }^{* * *}$ significant $p<0.001$. T100: 100\% N through DADRs; TMIN: Mineral control. 


\section{Discussion}

The chemical characteristics of the DADRs used in these experiments are positive for agronomic purposes. Haynes et al. [34] expected total organic matter contents (TOM) for DADRs between $40 \%$ and $70 \%$ and total organic carbon contents (TOC) between $20 \%$ and 50\%. The DADRs used in this experiment were consistent with these values and the high nutrient content also supports the idea of a highly nutritive by-product, as reported by other authors [35-37]. According to Haynes et al. [34], DADRs could have total nitrogen contents between $2 \%$ and $5 \%$ and in this trial the total $\mathrm{N}$ content was within that range. Furthermore, it is interesting to note that the low C:N ratio in DADRs is a sign of rapid mineralization, contrary to what has been verified for cattle manure where the $\mathrm{C}: \mathrm{N}$ ratio is approximately 50 [38]. As for heavy metal content, the recorded concentrations being lower than the current regulations (The Commission of the European Communities, 2006) require also indicates the chemical safety characteristics of DADRs. A possible problem for this material might be the slightly high salinity. However, research made in mid- and long-term periods with other organic materials characterized by high electrical conductivity, such as spent mushroom compost $[39,40]$ or cattle manure [41], did not show difficulties if the product was applied at correct levels. The application of this material in the fertilization of vegetable species proved positive, but at the same time somewhat variable results, especially in the first years. For example, in relation to the butterhead lettuce cultivation in the first year (S2), T100 produced significantly less than the mineral control, whereas T75 and T100 gave higher values in both lettuce varieties in the second year. In the first year, butterhead lettuce was transplanted in April, a month earlier than batavia lettuce, giving the former less opportunity for $\mathrm{N}$ uptake from the organic fertilizer. The yield obtained with T100 was as low as that of the nonfertilized treatment (T0), perhaps because of the closeness of the fertilization (contemporary for the two sequences) and the transplanting times, as well as the lower temperatures. In addition, since the two varieties of lettuce grown in the second year were transplanted at the same time and in late spring, when temperatures were high and rainfall intermediate, there were better conditions for the organic $\mathrm{N}$ to mineralize, and these treatments might have also benefited from residual mineral $\mathrm{N}$ derived from the organic fertilization of the previous crops. This explains why the treatments with higher content of DADRs presented the highest yields. In a similar experiment [42] using municipal solid waste (MSW) compost, two varieties of iceberg lettuce ('Audran' and 'Sagess') fertilized with high doses of compost $\left(\mathrm{N}: 160\right.$ and $\left.319 \mathrm{~kg} \cdot \mathrm{ha}^{-1}\right)$ produced a total biomass not different from those fertilized with chemical $\mathrm{N}$ $\left(84 \mathrm{~kg} \cdot \mathrm{ha}^{-1}\right)$.

Conversely to that found for lettuce in the second year, the complete substitution of mineral fertilization with DADRs in early and late chicory did not provide comparable production to TMIN in both crop successions. In the first case, the early fall crop had lower organic $\mathrm{N}$ availability because of the shorter growing cycle and the decreasing temperature slowed down organic $\mathrm{N}$ mineralization. In the second one, T100 treatment was not able to support late radicchio growth despite the longer cycle. This result was probably due to the reduction of mineralization process when low temperatures and high rainfall occur, partially in contrast with that reported by several authors $[7,15]$ who highlighted that $\mathrm{N}$ release by digestate can be comparable to mineral fertilizer. T75 produced a better yield because the mineral component supplied the initial $\mathrm{N}$ requirement for the plant and the digestates released enough nutrients for subsequent needs. Similar results were obtained in two different experiments using MSW compost as fertilizer, the first one in Florida with parsley (Petroselinum crispum (Mill.) Nyman)) and the second one in Nova Scotia with potatoes (Solanum tuberosum L.). In both cases, it was found that a combination of MSW compost and mineral fertilizer produced the same marketable yield as the $100 \%$ inorganic fertilizer $[43,44]$.

Benincasa et al. [45] indicated that the factors able to affect the NUE are: Crop varieties, which affect growth and development; agricultural practices (fertilization, irrigation, density, and plant spacing); and environmental factors (temperature, rainfall, and soil texture). In this mid-term experiment, a differential cumulative $\mathrm{N}$ uptake was observed between the two successions. Concerning the cumulative $\mathrm{N}$ uptake of marketable production, the crop that had the greatest impact on the differing 
trends of S1 from S2 was Swiss chard. This crop, unlike the catalogna chicory, showed a physiological ability to uptake a high amount of $\mathrm{N}$ to the harvested plant organ, the leaves, while residuals were minimized. This aspect is in agreement with that found by other authors [46,47]. However, as also observed in other experiments on related species such as stem chicory and red chicory [48,49], the catalogna chicory is characterized by a low nitrogen absorption efficiency, confirmed by low nitrate accumulation in tissues. Also with regard to the NHI, a strong effect of the cultivated species was observed, particularly for late cauliflower and melon in S1 and late chicory and melon in S2. These results, together with the influence of fertilizing treatments, can be attributed to the vegetable crop cycle length and to the weather conditions during the crop cycle. In summer transplanting, the warm weather conditions favored mineralization of soil organic matter, thus providing the crop an effective nutritional status. T75 was possibly different from the other treatments because the limited amount of mineral nitrogen might be immediately used by soil microorganisms to degrade the DADRs, thus reducing the "starter" effect experienced by T50 and T100. In the former treatment, with a higher quantity of mineral $\mathrm{N}$, in the latter with higher abundance of DADRs, releasing readily usable nutrients. In relation to melon and its NHI, T50 was different from T75 and both were different from T100. Here, when considering the weather conditions during the crop cycle, the abundant rainfall likely reduced the efficiency of most of the mineral fertilization, probably due to nitrogen leaching. Moreover, the noticeable, but nonremarkable, increase registered with T100 as compared to TMIN can be explained by the reduced temperatures during the first month of the crop cycle, which delayed the DADRs' mineralization. In both rotations some general conclusions can be drawn: Crops with a short crop cycle (i.e., lettuce) were not significantly influenced by DADR application, compared to mineral fertilization treatment, in regards to NHI; moreover, for some crops (potato), the distribution of DADRs marginally improved NHI. In other cases (chicory, Swiss chard, and tomato), the application of DADRs caused a quantitative increase of crop residues, reducing the $\mathrm{N}$ content in marketable production. Within the same crop, it is interesting to note that growth cycle length, and consequently the weather conditions, were able to modify NHI. For example, in cauliflower and chicory, it is evident that late varieties displayed a higher NHI from DADR application. Such results show the greater ability of organic matter to release nutrients in the long term, even with suboptimal weather conditions. Conversely, in the case of TMIN, the applied N was probably easily leached by the generous autumn-winter rainfall.

The nitrogen use efficiency in terms of AE, PE, and ARE provided some useful information for identifying the effect of the application of DADRs in a mid-term succession. In general, as previously reported for other variables, the results are related to both the fertilization treatment and the growing season. However, the general trend shows that for most of the crops TMIN exerted a higher efficiency compared to T100. Some exceptions, showing a favorable trend for T100, were observed for tomato. In this experiment, potato showed lower $\mathrm{N}$ uptake values compared to other crops in both successions. This result could be linked to the heavy rains that occurred during the crop cycle that reduced nitrogen availability for the crop. Contrary to what was verified by potato, the NUE was higher for species such as late and early cauliflower when compared with other studies [50]. The same authors, evaluating the effect of the application of solid fraction digestate in a short crop rotation, showed AE of $-0.93 \mathrm{~kg} \mathrm{~kg}^{-1}$ of $\mathrm{N}$ for spring cauliflower, whereas in this experiment AE was 120.9 and $60.3 \mathrm{~kg} \mathrm{~kg}^{-1}$, respectively, for T100 and TMIN in late cauliflower. This demonstrates the effect of the warm season, which speeds up the mineralization of the DADRs' organic matter. PE and ARE values were also higher than those reported by Maucieri et al. [50]. For other species, such as lettuces, the PE values detected, even if not statistically significant among the different treatments, are in line with that verified by Nicoletto et al. [51], with close to $1000 \mathrm{~kg} \mathrm{~kg}^{-1}$ of nitrogen supplied. For these short-cycle crops, if carried out in cold periods, it would be desirable to anticipate the distribution of DADRs at least three weeks before the transplant, in order to favor nutrients' remobilization, as suggested by Sánchez et al. [52]. 


\section{Conclusions}

DADRs are valuable organic materials that can be used as fertilizers in horticulture. Having low $\mathrm{C} / \mathrm{N}$ ratio, DADRs can be sufficiently mineralized in all seasons. Indeed, in 13 of 16 tested crops T100 was characterized by the same or higher yield than TMIN. Thus, DADRs can be used as a "fertilizer" in crop management without compromising yield. Specific knowledge is required to properly manage DADRs to maximize their beneficial effect on vegetable crops. For early spring crops, a combination of $50 \%$ organic and $50 \%$ mineral $\mathrm{N}$ could be recommended. The mineral $\mathrm{N}$ satisfies the initial crop requirement for this element, whereas the organic $\mathrm{N}$ supplies the later needs, following the mineralization process. For spring-summer crops, high temperatures during the crop cycle can positively influence the organic matter mineralization, allowing the use of $100 \%$ DADRs to support crop $\mathrm{N}$ requirements. For early fall crops, DADR treatments did not show $\mathrm{N}$ recovery as much as the mineral treatment, probably because of the proximity of the fertilization to the transplanting times. For crops that were harvested in late autumn or early winter, some DADR treatments showed a better $\mathrm{N}$ recovery and a better agronomic performance. Moreover, an adequate span of time, ranging between two to three years, could be suggested to farmers for this innovative organic material to reach a soil nutritional balance comparable to a standard mineral fertilization, and to fully replace it.

Author Contributions: Conceptualization, P.S., C.N., and G.Z.; methodology, C.N.; validation, C.N. and L.D.C.; formal analysis, C.N. and L.D.C.; investigation, C.N.; resources, P.S. and G.Z.; data curation, C.N., L.D.C., and G.Z.; writing-original draft preparation, C.N. and L.D.C.; writing—review and editing, P.S., C.N., L.D.C., and G.Z.; visualization, C.N., L.D.C., and G.Z.; supervision, P.S. and G.Z.; project administration, P.S.; funding acquisition, P.S.

Funding: This research was funded by Distillerie Mazzari Spa “Valorizzazione del digestato anaerobico derivante dall'industria di distallazione nell'ortoflorovivaismo."

Conflicts of Interest: The authors declare no conflict of interest.

\section{References}

1. Hollinger, E.; Baginska, B.; Cornish, P.S. Factors influencing soil and nutrient loss in storm water from a market garden. In Proceedings of the 9th Australian Agronomy Conference, Wagga, Australia, 20-23 July 1998; Australian Society of Agronomy: Parkville, VIC, Australia, 1998; pp. 741-744.

2. Romaniuk, R.; Giuffré, L.; Costantini, A.; Nannipieri, P. Assessment of soil microbial diversity measurements as indicators of soil functioning in organic and conventional horticulture systems. Ecol. Indic. 2011, 11, 1345-1353. [CrossRef]

3. Coutinho, J.; Dalla Costa, L.; Borin, M.; Battilani, A.; Dolezal, F.; Bizik, J.; Mazurczyk, W.; Plauborg, F.L. One Single Value for Maximum N Application from Organic Residues: Is it Technically and Environmentally Sound? ESA Congress: Varsavia, Polonia, 2006.

4. Gaskell, M.; Smith, R.; Mitchell, J.; Koike, S.T.; Fouche, C.; Hartz, T.; Horwath, W.; Jackson, L. Soil Fertility Management for Organic Crops. 2006. Available online: https://escholarship.org/uc/item/1ws2d496 (accessed on 21 June 2019). [CrossRef]

5. Morelli, J. Environmental sustainability: A definition for environmental professionals. J. Environ. Sustain. 2011, 1, 2.

6. Weiland, P. Biogas production: Current state and perspectives. Appl. Microbiol. Biotechnol. 2010, 85, 849-860. [CrossRef] [PubMed]

7. Nkoa, R. Agricultural benefits and environmental risks of soil fertilization with anaerobic digestates: A review. Agron. Sustain. Dev. 2014, 34, 473-492. [CrossRef]

8. Teglia, C.; Tremier, A.; Martel, J.L. Characterization of solid digestates: Part 1, review of existing indicators to assess solid digestates agricultural use. Waste Biomass Valori. 2011, 2, 43-58. [CrossRef]

9. Insam, H.; Gómez-Brandón, M.; Ascher, J. Manure-based biogas fermentation residues-Friend or foe of soil fertility? Soil Biol. Biochem. 2015, 84, 1-14. [CrossRef]

10. Qi, G.; Pan, Z.; Sugawa, Y.; Andriamanohiarisoamanana, F.J.; Yamashiro, T.; Iwasaki, M.; Umetsu, K. Comparative fertilizer properties of digestates from mesophilic and thermophilic anaerobic digestion of dairy manure: Focusing on plant growth promoting bacteria (PGPB) and environmental risk. J. Mater. Cycles Waste Manag. 2018, 20, 1448-1457. [CrossRef] 
11. Jaffar, M.; Pang, Y.; Yuan, H.; Zou, D.; Liu, Y.; Zhu, B.; Li, X. Wheat straw pretreatment with KOH for enhancing biomethane production and fertilizer value in anaerobic digestion. Chin. J. Chem. Eng. 2016, 24, 404-409. [CrossRef]

12. Yan, X.; Gong, W. The role of chemical and organic fertilizers on yield, yield variability and carbon sequestration-Results of a 19-year experiment. Plant Soil 2010, 331, 471-480. [CrossRef]

13. Garg, S.; Bahl, G.S. Phosphorus availability to maize as influenced by organic manures and fertilizer $P$ associated phosphatase activity in soils. Bioresour. Technol. 2008, 99, 5773-5777. [CrossRef]

14. Bouallagui, H.; Lahdheb, H.; Romdan, E.B.; Rachdi, B.; Hamdi, M. Improvement of fruit and vegetable waste anaerobic digestion performance and stability with co-substrates addition. J. Environ. Manag. 2009, 90, 1844-1849. [CrossRef] [PubMed]

15. Möller, K.; Müller, T. Effects of anaerobic digestion on digestate nutrient availability and crop growth: A review. Eng. Life Sci. 2012, 12, 242-257. [CrossRef]

16. Alburquerque, J.A.; De la Fuente, C.; Campoy, M.; Carrasco, L.; Nájera, I.; Baixauli, C.; Caravaca, F.; Roldàn, A.; Cegarra, J.; Bernal, M.P. Agricultural use of digestate for horticultural crop production and improvement of soil properties. Eur. J. Agron. 2012, 43, 119-128. [CrossRef]

17. Montemurro, F.; Ferri, D.; Tittarelli, F.; Canali, S.; Vitti, C. Anaerobic digestate and on-farm compost application: Effects on lettuce (Lactuca sativa L.) crop production and soil properties. Compost Sci. Util. 2010, 18, 184-193. [CrossRef]

18. Lošák, T.; Zatloukalová, A.; Szostková, M.; Hlušek, J.; Fryč, J.; Vítěz, T. Comparison of the effectiveness of digestate and mineral fertilisers on yields and quality of kohlrabi (Brassica oleracea, L.). Acta Univ. Agric. Silvic. Mendel. Brun. 2014, 59, 117-122. [CrossRef]

19. Montemurro, F.; Ciaccia, C.; Leogrande, R.; Ceglie, F.; Diacono, M. Suitability of different organic amendments from agro-industrial wastes in organic lettuce crops. Nutr. Cycl. Agroecosyst. 2015, 102, 243-252. [CrossRef]

20. Lošák, T.; Hlušek, J.; Válka, T.; Elbl, J.; Vítěz, T.; Bělíková, H.; Von Bennewitz, E. The effect of fertilisation with digestate on kohlrabi yields and quality. Plant Soil Environ. 2016, 62, 274-278. [CrossRef]

21. Frøseth, R.B.; Bakken, A.K.; Bleken, M.A.; Riley, H.; Pommeresche, R.; Thorup-Kristensen, K.; Hansen, S. Effects of green manure herbage management and its digestate from biogas production on barley yield, $\mathrm{N}$ recovery, soil structure and earthworm populations. Eur. J. Agron. 2014, 52, 90-102. [CrossRef]

22. Bjornsson, W.J.; Nicol, R.W.; Dickinson, K.E.; McGinn, P.J. Anaerobic digestates are useful nutrient sources for microalgae cultivation: Functional coupling of energy and biomass production. J. Appl. Phycol. 2013, 25, 1523-1528. [CrossRef]

23. Nicoletto, C.; Galvao, A.; Maucieri, C.; Borin, M.; Sambo, P. Distillery anaerobic digestion residues: A new opportunity for sweet potato fertilization. Sci. Hortic. 2017, 225, 38-47. [CrossRef]

24. Novello, V. Filiera vitivinicola: Valorizzare residui e sottoprodotti. L'Informatore Agrar. 2015, 33, 61-63.

25. Schenk, H.J. Root competition: Beyond resource depletion. J. Ecol. 2006, 94, 725-739. [CrossRef]

26. Booij, R.; Meurs, B. Supplementary nitrogen application in leeks, based on determination of crop nitrogen status. Acta Hortic. 2002, 571, 155-161. [CrossRef]

27. Han, M.; Okamoto, M.; Beatty, P.H.; Rothstein, S.J.; Good, A.G. The genetics of nitrogen use efficiency in crop plants. Annu. Rev. Genet. 2015, 49, 269-289. [CrossRef]

28. Rahn, C.R.; Bending, G.D.; Turner, M.K.; Lillywhite, R.D. Management of N mineralization from crop residues of high $\mathrm{N}$ content using amendment materials of varying quality. Soil Use Manag. 2003, 19, 193-200. [CrossRef]

29. Gastal, F.; Lemaire, G.; Durand, J.L.; Louarn, G. Quantifying crop responses to nitrogen and avenues to improve nitrogen-use efficiency. In Crop Physiology; Academic Press: Cambridge, MA, USA, 2015; pp. 161-206.

30. Perelli, M.; Graziano, P.L.; Calzavara, R. Nutrire le Piante; Arvan Editore: Venezia, Italy, 2009.

31. Fageria, N.K.; De Morais, O.P.; Dos Santos, A.B. Nitrogen use efficiency in upland rice genotypes. J. Plant Nutr. 2010, 33, 1696-1711. [CrossRef]

32. Nelson, D.W.; Sommers, L.E. Total carbon, organic carbon, and organic matter. In Methods of Soil Analysis Part 3-Chemical Methods (Methodsofsoilan3); Soil Science Society of America, American Society of Agronomy: Madison, WI, USA, 1996; pp. 961-1010.

33. Zancan, S.; Cesco, S.; Ghisi, R. Effect of UV-B radiation on iron content and distribution in maize plants. Environ. Exp. Bot. 2006, 55, 266-272. [CrossRef] 
34. Haynes, R.J.; Murtaza, G.; Naidu, R. Inorganic and organic constituents and contaminants of biosolids: Implications for land application. Adv. Agron. 2009, 104, 165-267.

35. Salminen, E.; Rintala, J.; Harkonen, J.; Kuitunen, M.; Hogmander, H.; Oikari, A. Anaerobically digested poultry slaughterhouse wastes as fertiliser in agriculture. Bioresour. Technol. 2001, 78, 81-88. [CrossRef]

36. Tambone, F.; Genevini, P.; D'Imporzano, G.; Adani, F. Assessing amendment properties of digestate by studying the organic matter composition and the degree of biological stability during the anaerobic digestion of the organic fraction of MSW. Bioresour. Technol. 2009, 100, 3140-3142. [CrossRef]

37. Tambone, F.; Scaglia, B.; D'Imporzano, G.; Schievano, A.; Orzi, V.; Salati, S.; Adani, F. Assessing amendment and fertilizing properties of digestates from anaerobic digestion through a comparative study with digested sludge and compost. Chemosphere 2010, 81, 577-583. [CrossRef]

38. Loh, T.C.; Lee, Y.C.; Liang, J.B.; Tan, D. Vermicomposting of cattle and goat manures by Eisenia foetida and their growth and reproduction performance. Bioresour. Technol. 2005, 96, 111-114. [CrossRef]

39. Gobbi, V.; Bonato, S.; Nicoletto, C.; Zanin, G. Spent mushroom substrate as organic fertilizer: Vegetable organic trials. Acta Hortic. 2016, 1146, 49-56. [CrossRef]

40. Gobbi, V.; Nicoletto, C.; Zanin, G.; Sambo, P. Specific humus systems from mushrooms culture. Appl. Soil Ecol. 2017, 123, 709-713. [CrossRef]

41. Viaene, J.; Nelissen, V.; Vandecasteele, B.; Willekens, K.; De Neve, S.; Reubens, B. Field storage conditions for cattle manure to limit nitrogen losses and optimise fertiliser value. Anim. Prod. Sci. 2017, 57, 2148-2166. [CrossRef]

42. Fagnano, M.; Adamo, P.; Zampella, M.; Fiorentino, N. Environmental and agronomic impact of fertilization with composted organic fraction from municipal solid waste: A case study in the region of Naples, Italy. Agric. Ecosyst. Environ. 2011, 141, 100-107. [CrossRef]

43. Mylavarapu, R.S.; Zinati, G.M. Improvement of soil properties using compost for optimum parsley production in sandy soils. Sci. Hortic. 2009, 120, 426-430. [CrossRef]

44. Mkhabela, M.S.; Warman, P.R. The influence of municipal solid waste compost on yield, soil phosphorus availability and uptake by two vegetable crops grown in a Pugwash sandy loam soil in Nova Scotia. Agric. Ecosyst. Environ. 2005, 106, 57-67. [CrossRef]

45. Benincasa, P.; Guiducci, M.; Tei, F. The nitrogen use efficiency: Meaning and sources of variation-Case studies on three vegetable crops in Central Italy. HortTechnology 2011, 21, 266-273. [CrossRef]

46. Santamaria, P.; Elia, A.; Serio, F.; Gonnella, M.; Parente, A. Comparison between nitrate and ammonium nutrition in fennel, celery, and Swiss chard. J. Plant Nutr. 1999, 22, 1091-1106. [CrossRef]

47. Hessini, K.; Lachaal, M.; Cruz, C.; Soltani, A. Role of ammonium to limit nitrate accumulation and to increase water economy in wild Swiss Chard. J. Plant Nutr. 2009, 32, 821-836. [CrossRef]

48. Bianco, V.V.; Santamaria, P.; Elia, A. Nutritional value and nitrate content in edible wild species used in southern Italy. Acta Hortic. 1998, 467, 71-90. [CrossRef]

49. Filippini, M.F.; Cavagnaro, J.B.; Nicoletto, C.; Pimpini, F.; Sambo, P. Influence of fertilization on the growth of radicchio" Rosso di Chioggia. Rev. Fac. Cienc. Agrar. 2011, 43, 111-131.

50. Maucieri, C.; Nicoletto, C.; Caruso, C.; Sambo, P.; Borin, M. Effects of digestate solid fraction fertilisation on yield and soil carbon dioxide emission in a horticulture succession. Ital. J. Agron. 2017, 12, 116-123. [CrossRef]

51. Nicoletto, C.; Santagata, S.; Zanin, G.; Sambo, P. Effect of the anaerobic digestion residues use on lettuce yield and quality. Sci. Hortic. 2014, 180, 207-213. [CrossRef]

52. Sánchez, L. Effect of timing of application of municipal solid waste compost on $\mathrm{N}$ availability for crops in central Spain. Biol. Fertil. Soils 1997, 25, 136-141. [CrossRef]

(C) 2019 by the authors. Licensee MDPI, Basel, Switzerland. This article is an open access article distributed under the terms and conditions of the Creative Commons Attribution (CC BY) license (http://creativecommons.org/licenses/by/4.0/). 